\title{
Methylation mechanism of tin(II) by methylcobalamin in aquatic systems
}

\author{
Baowei Chen, Qunfang Zhou, Jiyan Liu, Dandan Cao, Thanh Wang, Guibin Jiang *
}

State Key Laboratory of Environmental Chemistry and Ecotoxicology, Research Center of Eco-Environmental Sciences, Chinese Academy of Sciences, P.O. Box 2871, Beijing 100085, PR China

Received 29 July 2006; received in revised form 31 December 2006; accepted 4 January 2007

Available online 14 February 2007

\begin{abstract}
The methylation reaction of $\operatorname{tin}(\mathrm{II})$ with methylcobalamin $\left(\mathrm{CH}_{3} \mathrm{~B}_{12}\right)$ in aquatic systems was modeled in the laboratory. The products were detected by a sensitive gas chromatography-flame photometric detector (GC-FPD), and further identified by gas chromatographymass spectrometry (GC-MS). Both monomethyltin (MMT) and dimethyltin (DMT) were found as methylation products. Three important effecting factors during the methylation reaction, salinity, $\mathrm{pH}$ and aerobic or anaerobic, were studied. The results showed that methyl group can be transferred from $\mathrm{CH}_{3} \mathrm{~B}_{12}$ to tin in aquatic solutions as a radical or carbonium, as well as a carbanion. Two explanations for the $\mathrm{pH}$-dependency of the methylation reaction between $\operatorname{tin}(\mathrm{II})$ and $\mathrm{CH}_{3} \mathrm{~B}_{12}$ were proposed: $\mathrm{pH}$-dependency of the equilibrium states of $\mathrm{CH}_{3} \mathrm{~B}_{12}$, and $\mathrm{pH}$-dependency of inorganic tin(II) species whose reactivity vary with the redox potential in the solution. Salinity can influence the activity of the methyl donor, which cause changes in the methylation efficiency. Kinetic experiments showed that the methylation reaction was pseudo-first-order for $\mathrm{CH}_{3} \mathrm{~B}_{12}$.
\end{abstract}

(C) 2007 Elsevier Ltd. All rights reserved.

Keywords: Methylation; Tin(II); Monomethyltin; Dimethyltin; Methylcobalamin; Reaction kinetics

\section{Introduction}

The methylation of inorganic tin including abio- and bio-methylations is one of the important transportation and transformation pathways of tin compounds in the environment. Researches on methylation of inorganic tin have drawn great interest of environmental concern because of their increasing toxicity to animals and human beings when inorganic tin compounds are transformed into their methylated forms.

To date, methyltin compounds have been globally found in various environmental matrices such as sea water (Braman and Tompkins, 1979), estuarine water (Donard et al., 1986), fresh water (Byrd and Andreae, 1982), lake water (Maguire et al., 1982), waste water (Donard et al., 1993), sediments (Tugrul et al., 1983; Maguire et al., 1986; Schebek

\footnotetext{
${ }^{*}$ Corresponding author. Tel./fax: +86 1062849179.

E-mail address: gbjiang@rcees.ac.cn (G. Jiang).
}

et al., 1991), as well as various biological samples such as fish, oyster, mussels, domestic chicken egg shell and macroalgae (Seidel et al., 1980; Han and Weber, 1988; Quevauviller et al., 1989). A number of reports have testified that environmental methylation of inorganic tin might be an important source of methyltin compounds.

Inorganic tin can be methylated in the environment if appropriate methyl donors exist. So far, four kinds of main methyl donors including $S$-adenosylmethionine (SAM), methyl iodide $\left(\mathrm{CH}_{3} \mathrm{I}\right)$, methylcobalamin $\left(\mathrm{CH}_{3} \mathrm{~B}_{12}\right)$ and $N^{5}$-methyltetrahydrosylmethionine, have been found in the environment. As for $\mathrm{CH}_{3} \mathrm{~B}_{12}$, it can transfer methyl groups to inorganic metal ions by three ways: carbanion, methyl radical and carbanium. Dizikes et al. (1978) studied the methylation reaction of $\mathrm{CH}_{3} \mathrm{~B}_{12}$ and tin(II) in strong acidic condition ( $\mathrm{pH} 1.0)$ and in the presence of oxidants such as aquocobalamin and Fe(III). Moreover, Fanchiang and Wood (1981) studied the methylation of tin(II) by $\mathrm{CH}_{3} \mathrm{~B}_{12}$ in $1.0 \mathrm{M} \mathrm{HCl}$ in the presence of oxygen and 
aquocobalamin. Their results demonstrated that tin(II) could only be methylated by $\mathrm{CH}_{3} \mathrm{~B}_{12}$ under strong acidic conditions. However, Ashby and Craig (1991) showed that tin(II) can be methylated by $\mathrm{CH}_{3} \mathrm{~B}_{12}$ under more environmentally relevant conditions. Their results significantly differ from that of Dizikes and Fanchiang. Obviously, different methyl-transfer mechanisms from $\mathrm{CH}_{3} \mathrm{~B}_{12}$ to tin(II) exist under different conditions, and these need to be further investigated.

In this paper, the methylation reaction of tin(II) with $\mathrm{CH}_{3} \mathrm{~B}_{12}$ was studied under different conditions. Factors including $\mathrm{pH}$, salinity and aerobic or anaerobic conditions were studied during the methylation procedure to elucidate the potential mechanisms. The methyltin products were derivatized by Grignard reaction and analyzed with sensitive GC-FPD.

\section{Materials and methods}

\subsection{Materials}

All reagents were obtained commercially and used without further purification unless otherwise stated. The standards of trimethyltin chloride (TMT, 98\%), dimethyltin dichloride (DMT, 97\%) and monomethyltin trichloride (MMT, 97\%) were obtained from Aldrich Chem. Co. (USA). $\mathrm{CH}_{3} \mathrm{~B}_{12}(99.5 \%)$ was purchased from PHENTEX CORP. (USA). Stannous chloride $(98 \%)$ was obtained from Beijing Yili Company of Chemical Reagents (China).

\subsection{Reaction design}

In general, methylation reaction was performed in $40 \mathrm{ml}$ of aqueous solutions in darkness at about $30^{\circ} \mathrm{C}$. The stock solution of $0.2 \mathrm{M} \mathrm{SnCl}_{2}$ in $2 \mathrm{M} \mathrm{HCl}$ was used as inorganic tin source. The $\mathrm{pH}$ value of the reaction system was adjusted by $0.1 \mathrm{M} \mathrm{NaOH}$ and determined by a $\mathrm{pH}$ meter (HANNA instruments $\mathrm{pH} 211 \mathrm{C}$ equipped with an $\mathrm{HI}$ 1200B glass-body combination $\mathrm{pH}$ electrode). The salinity of solution was adjusted with $5 \mathrm{M} \mathrm{NaCl}$ solution. The reactor was covered with aluminium foil to keep it dark. In order to achieve anaerobic condition, the reaction system was placed in an ultrasonic bath to degas for about 10 min and $\mathrm{N}_{2}$ was bubbled through the solution. The aerobic condition was obtained with the reaction vial exposed to the open air. $\mathrm{CH}_{3} \mathrm{~B}_{12}$ solution $(0.2 \mathrm{mM}), \mathrm{NaCl}$ solution and inorganic tin were added into the reaction vial in sequence, and then the $\mathrm{pH}$ of the solution was adjusted. The final concentration of $\mathrm{CH}_{3} \mathrm{~B}_{12}$ in the reaction system was $0.04 \mathrm{mM}$. Concentrations of methyltin compounds in the reaction system were monitored during the reaction procedure for kinetic analysis.

\subsection{Chemical analysis for methyltin compounds}

A GC-9 A gas chromatograph (Shimadzu, Japan) equipped with a capillary column (HP-1, $25 \mathrm{~m} \times 0.32 \mathrm{~mm}$ i.d. $\times 0.17 \mu \mathrm{m}$ ) was used for quantitative analysis throughout the experiment. A laboratory-made flame photometric detector using quartz surface-induced luminescence (QSILFPD) was used to measure the methyltin compounds. Its configuration, application and evaluation have been reported earlier (Jiang and Xu, 1996; Jiang et al., 1996). For further identification of methyltin products, Agilent $5793 \mathrm{~N}$ GC-MS with a capillary column (HP-5, $30 \mathrm{~m} \times$ $0.25 \mathrm{~mm}$ i.d. $\times 0.25 \mu \mathrm{m})$ was used. Detailed operation parameters of GC-QSIL-FPD and GC-MS are listed in Table 1.

Detailed sample preparation procedure has previously been described by Chen et al. (2006). In short, water samples were taken out from the reaction system and placed in a centrifugation tube together with citric acid- $\mathrm{NaH}_{2} \mathrm{PO}_{4}$ buffer solution ( $\mathrm{pH}$ 5.0). The internal standard $\left(\mathrm{MeSnPr}_{3}\right)$ and $0.1 \%$ tropolone-cyclohexane were added in sequence. The mixture was extracted in an ultrasonic bath and centrifuged twice at $3000 \mathrm{r} \mathrm{min}^{-1}$. Then, the combined organic phases were dried using anhydrous $\mathrm{Na}_{2} \mathrm{SO}_{4}$ and reacted with $\mathrm{n}-\mathrm{PeMgBr}$ (Grignard reagent) in an ultrasonic bath. Subsequently, excess Grignard reagent was eliminated by the addition of $5 \%(v / v) \mathrm{H}_{2} \mathrm{SO}_{4}$ solution, and the organic phase was purified by anhydrous $\mathrm{Na}_{2} \mathrm{SO}_{4}$ and Florisil. Finally, the eluted organic phase was concentrated to $2 \mathrm{ml}$ under a stream of nitrogen.

Earlier works have evaluated this analytical method as having good reproducibility and reliability for tin compounds, and it was also successfully applied to different

Table 1

Operation conditions for the analytical instruments

\begin{tabular}{|c|c|}
\hline \multicolumn{2}{|l|}{$G C-Q S I L-F P D$} \\
\hline $\begin{array}{l}\text { Injector } \\
\text { temperature }\end{array}$ & $220^{\circ} \mathrm{C}$ \\
\hline $\begin{array}{l}\text { Oven temperature } \\
\text { program }\end{array}$ & $\begin{array}{l}\text { Initial temp: } 50^{\circ} \mathrm{C} \text {; initial time: } 2 \mathrm{~min} \text {; rate: } \\
10^{\circ} \mathrm{C} \min ^{-1} \text {; final temp: } 200^{\circ} \mathrm{C} \text {; final time: } 5 \mathrm{~min}\end{array}$ \\
\hline Carrier gas & $\mathrm{N}_{2}$ \\
\hline $\begin{array}{l}\text { Column head } \\
\text { pressure }\end{array}$ & $260 \mathrm{kPa}$ \\
\hline $\begin{array}{l}\text { Detector } \\
\text { temperature }\end{array}$ & $160^{\circ} \mathrm{C}$ \\
\hline Flux of hydrogen & $260 \mathrm{ml} \mathrm{min}-1$ \\
\hline Flux of air & $90 \mathrm{ml} \mathrm{min}^{-1}$ \\
\hline Interference filter & $394 \mathrm{~nm}$ \\
\hline$G C-M S$ & \\
\hline $\begin{array}{l}\text { Injector } \\
\text { temperature }\end{array}$ & $220^{\circ} \mathrm{C}$ \\
\hline $\begin{array}{l}\text { Oven temperature } \\
\text { program }\end{array}$ & $\begin{array}{l}\text { Initial temp: } 50^{\circ} \mathrm{C} \text {; initial time: } 3 \mathrm{~min} \text {; rate: } \\
20^{\circ} \mathrm{C} \min ^{-1} \text {; final temp: } 280^{\circ} \mathrm{C} \text {; final time: } 10 \mathrm{~min}\end{array}$ \\
\hline Carrier gas & $\mathrm{Ar}_{2}$ \\
\hline Flux of carrier gas & $1.0 \mathrm{ml} \mathrm{min}-1$ \\
\hline Split ratio & $10: 1$ \\
\hline $\begin{array}{l}\text { Interface } \\
\quad \text { temperature }\end{array}$ & $250^{\circ} \mathrm{C}$ \\
\hline Detector volts & $1718 \mathrm{~V}$ \\
\hline Solvent cut time & $3 \mathrm{~min}$ \\
\hline Acquisition time & $11 \mathrm{~min}$ \\
\hline Mass range & $40-300 \mathrm{u}$ \\
\hline Interval & 2.83 \\
\hline Acquisition mode & Full scan \\
\hline
\end{tabular}


environmental samples (Jiang et al., 1996; Jiang et al., 2000). In this study, the limits of detection for MMT and DMT were $27 \mathrm{ng} \mathrm{ml}^{-1}$ and $11 \mathrm{ng} \mathrm{ml}^{-1}$, respectively. Limits

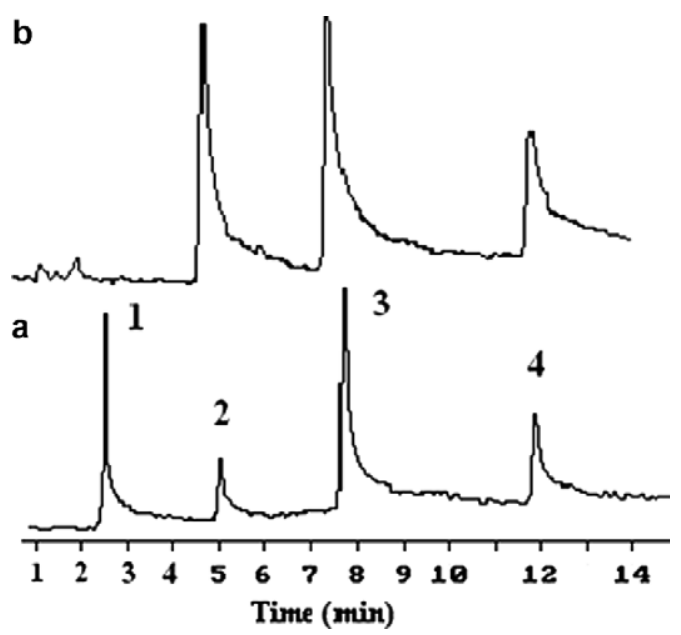

Fig. 1. Chromatogram of standard substances and the reaction products (a) standard substances and (b) reaction products, 1 - TMT, 2 - internal standard, 3 - DMT, 4 - MMT. of detection were calculated as three times the baseline noise. The relative standard deviation (RSD) for MMT and DMT were $6.7 \%$ and $9.4 \%$, respectively. The recoveries were $98.6 \%$ for MMT and $87.9 \%$ for DMT.

\section{Results and discussion}

The reaction products were identified by comparing their retention times in the chromatogram with those of standard substances, as shown in Fig. 1. It was clearly found that two compounds, MMT and DMT, were produced. The reaction products were further confirmed by mass spectrometry. Fig. 2 shows the mass spectrums of pentyl-derivatives of the reaction products. Characteristic fragment ions of the reaction products represent as follows: MMT, m/z $277\left(\mathrm{SnMePe}_{2}^{+}\right), 207\left(\mathrm{SnMePe}^{+}\right), 135$ $\left(\mathrm{SnMe}^{+}\right)$; DMT, $m / z 277\left(\mathrm{SnMePe}_{2}^{+}\right), 221\left(\mathrm{SnMe}_{2} \mathrm{Pe}^{+}\right)$, $207\left(\mathrm{SnMePe}^{+}\right), 151\left(\mathrm{SnMe}_{2}^{+}\right), 135\left(\mathrm{SnMe}^{+}\right)$. Comparative analysis showed that the fragment ions from the products were highly identical to those from the standards. As a result, MMT and DMT could be considered as the definite methylation products from the reaction between tin(II) and $\mathrm{CH}_{3} \mathrm{~B}_{12}$.

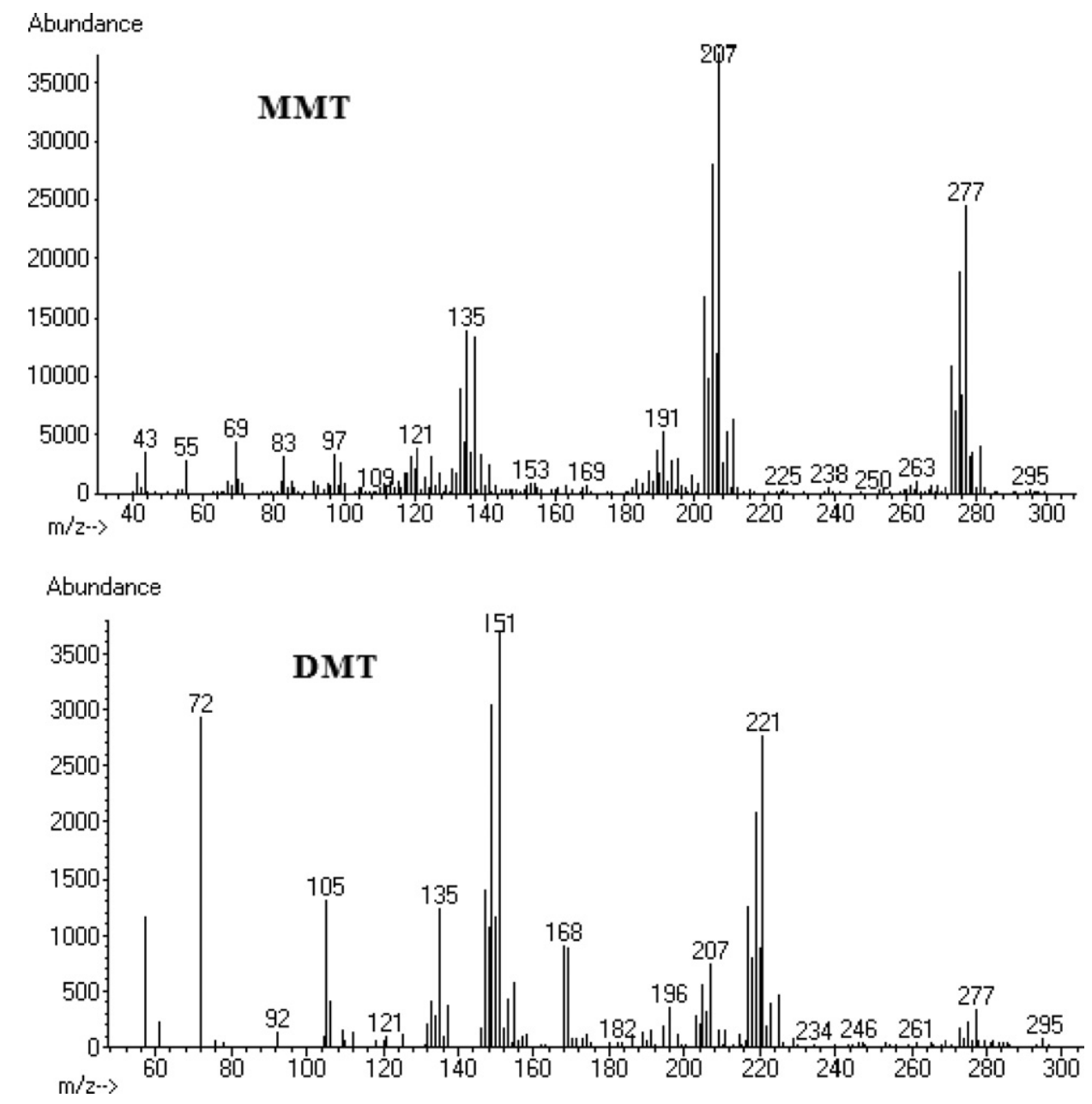

Fig. 2. Mass spectrum of pentyl-derivatives of methylation product for MMT and DMT. 


\subsection{Effect of $p H$}

The influence of $\mathrm{pH}$ on the methylation reaction of tin(II) with $\mathrm{CH}_{3} \mathrm{~B}_{12}$ in aquatic environments was studied under aerobic and anaerobic conditions (Fig. 3). Under aerobic conditions, the production of MMT peaked at $\mathrm{pH} 1.0$, and then declined with increasing $\mathrm{pH}$ value. A small amount of DMT was detected when the $\mathrm{pH}$ of the reaction system was equal to 1.0. The DMT concentration then increased when the $\mathrm{pH}$ value reached 2.0 , and thereafter changed slightly with the increase of $\mathrm{pH}$. An entirely different trend occurred under anaerobic conditions. When the solution $\mathrm{pH}$ was 1.0 , only a small amount of MMT was yielded from the methylation reaction of tin(II) with $\mathrm{CH}_{3} \mathrm{~B}_{12}$. Henceforth, the production of MMT rose with the increase of $\mathrm{pH}$ value. The trend for DMT is quite contrary to that of MMT under anaerobic condition. The highest level of DMT was produced at $\mathrm{pH} 1.0$, and decreased with increasing $\mathrm{pH}$ value. The concentration of DMT eventually became steady when the $\mathrm{pH}$ surpassed 5.0.

\subsection{Effect of salinity}

The effect of salinity on methylation reaction was also investigated (Fig. 4). A salinity range of $0-1.0 \mathrm{M}$, which covers the salinity levels normally found in aquatic environments (about $0.5 \mathrm{M}$ for seawater), was studied in our experiments. The results showed that different effects of salinity existed under aerobic and anaerobic condition. When the reaction system was open to air at $\mathrm{pH} 1.0$, the methylation efficiency of MMT increased with the rise of salinity and DMT was not detected. However, under protection of nitrogen and at $\mathrm{pH} 8.5$, the highest yield of MMT was obtained at salinity of $0.75 \mathrm{M}$, and the yield of DMT changed little with the alteration of the salinity.

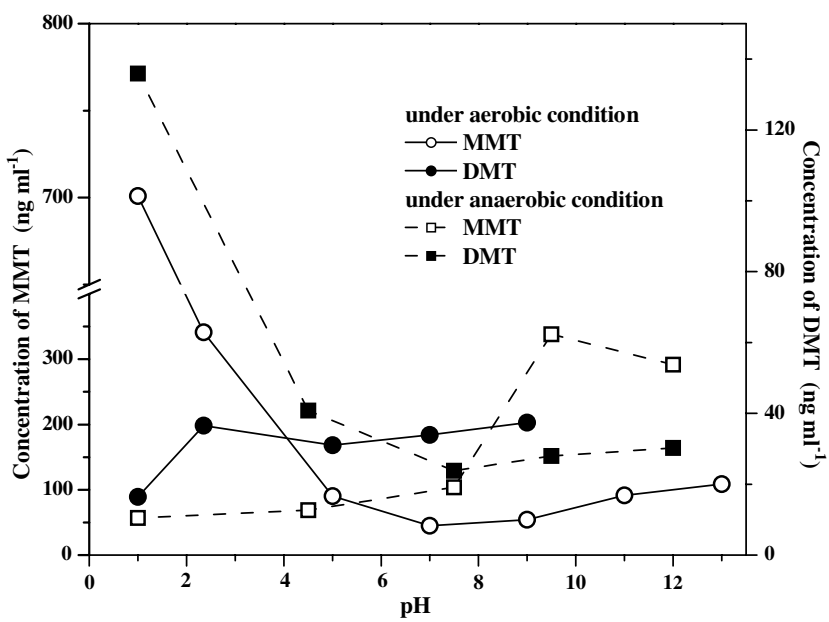

Fig. 3. The effect of $\mathrm{pH}$ on methylation reaction under aerobic and anaerobic conditions.

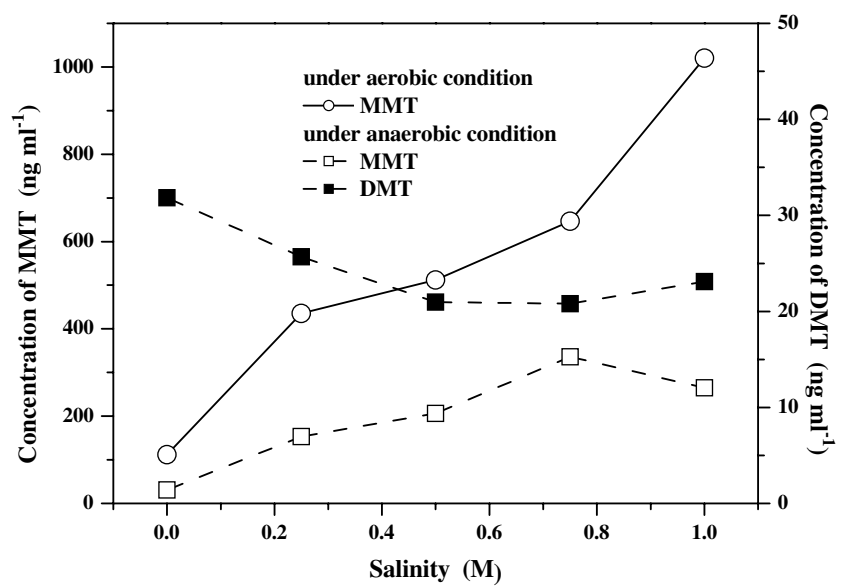

Fig. 4. The effect of salinity on methylation reaction under aerobic and anaerobic conditions.

\subsection{Reaction kinetics}

The kinetic curves under three different conditions were obtained by measuring the concentrations of the methyltin compounds at different reaction time (Fig. 5). The reaction rate was faster under strong acidic aerobic conditions than that in basic solutions under the protection of nitrogen. Large excess of $\mathrm{Sn}^{2+}$ over $\mathrm{CH}_{3} \mathrm{~B}_{12}$ was designed in the kinetics experiments so that the concentration of $\mathrm{Sn}^{2+}$ remained essentially constant in the methylation system. Therefore, the methylation reaction may be thought as pseudo-first-order for $\mathrm{CH}_{3} \mathrm{~B}_{12}$ because of the linear relationship between $\ln \left(\left(C_{0}-C\right) / \mathrm{C}_{0}\right)$ and the reaction time, where $C_{0}$ is the initial concentration of $\mathrm{CH}_{3} \mathrm{~B}_{12}$ and $C$ is the concentration of $\mathrm{CH}_{3} \mathrm{Sn}$ in the methylation system. The results of first-order kinetic fit are depicted in Fig. 6. The correlation coefficient $(R)$ was in the range of 0.95 0.97 . Thus, it could be deduced that this methylation reaction was first-order for $\mathrm{CH}_{3} \mathrm{~B}_{12}$. The first-order reaction

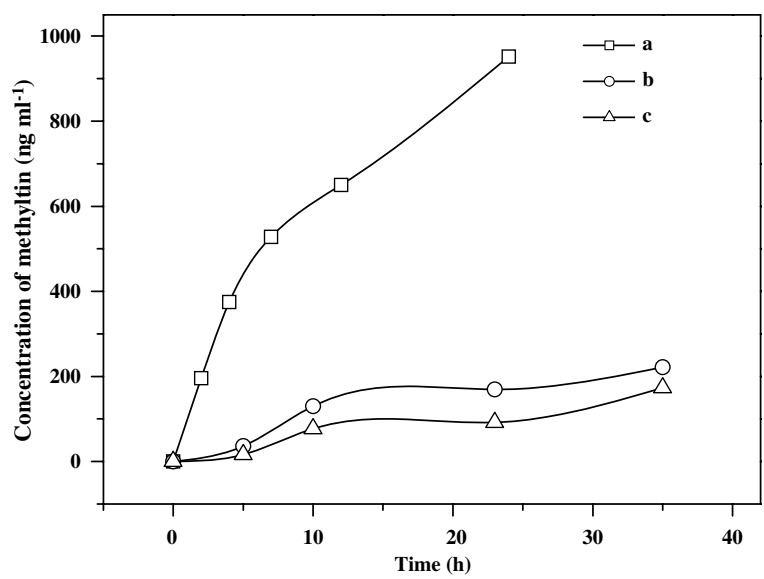

Fig. 5. Kinetic curves under different conditions $\left[\mathrm{CH}_{3} \mathrm{~B}_{12}\right]=0.04 \mathrm{mM}$; Salinity $=0.5 \mathrm{M} ; \mathrm{a}: \mathrm{pH} 1 .\left[\mathrm{Sn}^{2+}\right]=0.25 \mathrm{mM}$, aerobic codition; b: $\mathrm{pH} 10.5$, $\left[\mathrm{Sn}^{2+}\right]=0.5 \mathrm{mM}$, anaerobic condition; c: $\mathrm{pH} 8.5,\left[\mathrm{Sn}^{2+}\right]=0.5 \mathrm{mM}$, anaerobic condition. 


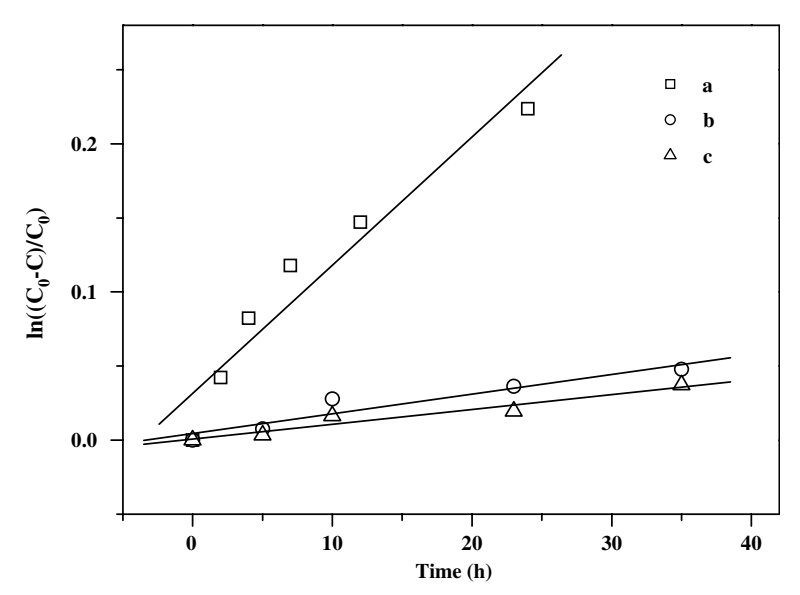

Fig. 6. First-order plots of $\ln \left(\left(C_{0}-C\right) / C_{0}\right)$ vs time a: $y=0.031+$ $0.0087 * x, \quad R=0.96 ; \quad$ b: $\quad y=0.0045+0.0013 * x, \quad R=0.95 ; \quad$ c: $\quad y=$ $0.00069+0.001 * x, R=0.97$.

rates were $0.0087 \mathrm{~h}^{-1}, 0.0013 \mathrm{~h}^{-1}$ and $0.001 \mathrm{~h}^{-1}$ under condition $\mathrm{a}, \mathrm{b}$ and $\mathrm{c}$, respectively.

\subsection{Reaction mechanism}

The GC-MS identification of the products from the methylation reaction demonstrated conclusively that tin(II) can be methylated by $\mathrm{CH}_{3} \mathrm{~B}_{12}$ under environmentally relevant conditions modeled in the laboratory:

$$
\begin{aligned}
& \mathrm{CH}_{3} \mathrm{~B}_{12}(\mathrm{III})+\mathrm{Sn}(\mathrm{II}) \rightarrow \mathrm{CH}_{3} \mathrm{Sn}(\mathrm{III})^{\cdot}+\mathrm{B}_{12}(\mathrm{II}) \\
& \mathrm{CH}_{3} \mathrm{Sn}(\mathrm{III})^{\cdot} \stackrel{\mathrm{O}_{2}}{\rightarrow} \mathrm{CH}_{3} \mathrm{Sn}(\mathrm{IV}) \\
& \mathrm{CH}_{3} \mathrm{~B}_{12}(\mathrm{III})+\mathrm{CH}_{3} \mathrm{Sn}(\mathrm{III})^{\circ} \rightarrow\left(\mathrm{CH}_{3}\right)_{2} \mathrm{Sn}(\mathrm{IV})+\mathrm{B}_{12}(\mathrm{II})
\end{aligned}
$$

$$
\begin{aligned}
& \mathrm{CH}_{3} \mathrm{~B}_{12}(\mathrm{III})+\mathrm{Sn}(\mathrm{II}) \rightarrow \mathrm{CH}_{3} \mathrm{Sn}(\mathrm{IV})+\mathrm{B}_{12}(\mathrm{I}) \\
& \mathrm{CH}_{3} \mathrm{~B}_{12}(\mathrm{III})+\mathrm{CH}_{3} \mathrm{Sn}(\mathrm{IV}) \rightarrow\left(\mathrm{CH}_{3}\right)_{2} \mathrm{Sn}(\mathrm{IV})+\mathrm{B}_{12}(\mathrm{III})
\end{aligned}
$$

$\mathrm{CH}_{3} \mathrm{~B}_{12}$ in aquatic solutions is subjected to an equilibrium between its "base on" form, in which 5,6-dimethylbenzimidazole is coordinated to the cobalt atom, and its uncoordinated "base off" form (Pratt, 1972). In strong acidic solutions with $\mathrm{pH}$ ranging from 0 to 1.0 , the primary form of $\mathrm{CH}_{3} \mathrm{~B}_{12}$ is "base off". In this case, the mechanism for methyl-transfer from $\mathrm{CH}_{3} \mathrm{~B}_{12}$ (base off) to tin(II) is thought as a reductive hemolytic cleavage of the $\mathrm{Co}-\mathrm{C}$ bond, in which a strongly reductive $\mathrm{CH}_{3} \mathrm{Sn}$ (III) intermediate is being produced. In the presence of an oxidant such as $\mathrm{O}_{2}$, this intermediate could be quickly oxidized to MMT(IV), as shown in reactions (1) and (2) (Fanchiang and Wood, 1981). This study finds evidence that higher concentration of DMT is being produced in the absence of $\mathrm{O}_{2}$ than in the presence of $\mathrm{O}_{2}$, which has not been reported before. A possible explanation might be that reaction (3) replaced reaction (2) as the main pathway in the methylation system under anaerobic conditions. In reaction (3), another methyl radical was again transferred from $\mathrm{CH}_{3} \mathrm{~B}_{12}$ to the intermediate $\mathrm{CH}_{3} \mathrm{Sn}(\mathrm{III})^{*}$. Beyond all doubt, oxidants such as molecular oxygen play a crucial role in determining which species (MMT or DMT) that are produced in the reaction between $\operatorname{tin}(\mathrm{II})$ and $\mathrm{CH}_{3} \mathrm{~B}_{12}$ under strong acidic condition. This conclusion is dissimilar to that of other studies which showed that oxidants only play an important role in the production of MMT (Fanchiang and Wood, 1981).

Although less methyltin was produced at $\mathrm{pH}$ higher than 1.0, these conditions are of more environmental significance, particularly within the $\mathrm{pH}$ range from 5 to 9 . The different equilibrium states of $\mathrm{CH}_{3} \mathrm{~B}_{12}$ may provide a possible explanation for the $\mathrm{pH}$-dependency of methyltin yield. Decreasing methylation efficiency with decreasing $\left[\mathrm{H}^{+}\right]$resulted from the decrease of "base off" form wherein water molecule occupied or unoccupied the sixth coordination position of $\mathrm{Co}$ atom. The five-coordinated $\mathrm{CH}_{3} \mathrm{~B}_{12}$ "base off" form is more reactive towards tin(II) than the six-coordinated "base on" form, according to the methyl radical transfer mechanism proposed by Fanchiang and Wood (1981). Moreover, another different mechanism for methylation reaction of tin(II) with $\mathrm{CH}_{3} \mathrm{~B}_{12}$ might also occur in solutions with $\mathrm{pH}$ higher than 1.0. Ashby and Craig (1991) suggested a carbonium transfer from $\mathrm{CH}_{3} \mathrm{~B}_{12}$ to tin(II). However, other oxidants such as oxygen could not be excluded from their reaction system. As a result, it cannot be judged that tin(II) was exclusively oxidized to tin(IV) by $\mathrm{CH}_{3} \mathrm{~B}_{12}$. It is found that MMT and DMT can be produced under $\mathrm{pH}$ values above 1.0, regardless of aerobic or anaerobic conditions. As the oxidant in the solution, oxygen had less effect on the methylation reaction when the reaction system was in solutions with $\mathrm{pH}$ higher than 1.0. Importantly, it can be definitely judged that no other compounds except $\mathrm{CH}_{3} \mathrm{~B}_{12}$ can oxidize tin(II) to tin(IV) in our methylation system under the protection of nitrogen. Hence there must exist an oxidative carbonium-transfer process in basic and weakly acidic solutions, in which tin(II) nucleophilically attack $\mathrm{CH}_{3} \mathrm{~B}_{12}$ to produce MMT. The aforementioned process is described in reaction (4). According to this mechanism, another reason for $\mathrm{pH}-$ dependency of methylation efficiency is the $\mathrm{pH}$-dependency of the inorganic tin(II) species in aquatic solutions (Chen et al., 2006). Due to the differences in their redox potential, different species of inorganic tin(II) have different reactivity with $\mathrm{CH}_{3} \mathrm{~B}_{12}$. Moreover, additional DMT was yielded when a small amount of MMT was further methylated by $\mathrm{CH}_{3} \mathrm{~B}_{12}$ in the reaction system; a carbanion-transfer process similar to reaction (5).

The effect of salinity on the methylation of tin(II) varied with $\mathrm{pH}$. In aerobic and strong acidic solutions, the methylation efficiency rose with the increase of the salinity (methyl radical transfer mechanism). Ashby and Craig (1991) provided two possible explanations: (1) tin(II) largely exist as $\mathrm{SnCl}_{2}$ and $\mathrm{SnCl}_{3}^{-}$in the presence of chloride ions; (2) The accelerating role of $\mathrm{Cl}^{-}$might be caused by its effect on the coordination of $\mathrm{CH}_{3} \mathrm{~B}_{12}$. When the reaction went along with carbonium-transfer mechanism at $\mathrm{pH} 8.5$ under anaerobic condition, the highest methylation efficiency was obtained at salinity of $0.75 \mathrm{M}$. This phenome- 
non is similar to the effect of salinity on methylation of tin(II) by methyl iodide(MeI), in which the methylation efficiency peaked at salinity of $0.1 \mathrm{M}$ (Chen et al., 2006). Methylation reaction of tin(II) with MeI is also considered as an oxidative process of carbonium-transfer. The effect of the salinity was explained as its influences on the activity of MeI. This same explanation can also be applied for the effect of salinity on the methylation reaction of tin(II) with $\mathrm{CH}_{3} \mathrm{~B}_{12}$. In the beginning, the increase of salinity would improve the reactivity of $\mathrm{CH}_{3} \mathrm{~B}_{12}$. After the concentration of chloride ion (weak nucleophilic ion) exceeds optimum value, it would obstruct the nucleophilic attack of tin(II) on carbonium. This is the first time to observe the difference between the influence of the salinity on the methylation reaction based on methyl radical transfer mechanism and that based on carbonium-transfer mechanism. As a result of our study, an interesting conclusion can be drawn that the efficiency of the methylation reaction of tin(II) with $\mathrm{CH}_{3} \mathrm{~B}_{12}$ in seawater is higher than that in freshwater under environmentally relevant conditions.

According to the kinetic experiments, methylation reaction of $\operatorname{tin}(\mathrm{II})$ with $\mathrm{CH}_{3} \mathrm{~B}_{12}$ followed two different reaction mechanisms which were both pseudo-first-order for $\mathrm{CH}_{3} \mathrm{~B}_{12}$. However, the first-order reaction rate of the methyl radical transfer mechanism was higher than that of the carboniumtransfer mechanism.

\section{Conclusion}

Two methylation products, MMT and DMT, were found in methylation systems of tin(II) reacting with $\mathrm{CH}_{3} \mathrm{~B}_{12}$. All investigated factors including salinity, $\mathrm{pH}$ and aerobic or anaerobic conditions had great effects on the methylation of tin(II). Methyl group can be transferred from $\mathrm{CH}_{3} \mathrm{~B}_{12}$ to tin in methylation systems as a methyl radical, a carbonium or carbanion. Oxidants such as oxygen played different roles under dissimilar conditions. When methylation reaction occurs in solutions of $\mathrm{pH}$ 1.0, MMT can be produced according to a one-step methyl radical transfer in the presence of oxygen, and DMT can be yielded according to a two-step methyl radical transfer under the protection of nitrogen. In solutions with $\mathrm{pH}$ higher than 1.0, MMT was yielded by a carbonium-transfer and further methylated to DMT by an additional carbanion-transfer. The influence of the salinity on the methylation reaction based on methyl radical transfer mechanism is greatly different from that based on carbonium-transfer mechanism. Kinetic experiments indicated that methylation reaction of tin(II) with $\mathrm{CH}_{3} \mathrm{~B}_{12}$ was pseudo-first-order for $\mathrm{CH}_{3} \mathrm{~B}_{12}$.

\section{Acknowledgements}

This work was jointly supported by the National Natural Science Foundation of China (20477053) and the National
Basic Research Program of China (2003CB415001 and 2005CB422206).

\section{References}

Ashby, J.R., Craig, P.J., 1991. The methylation of tin(II) chloride and tin(II) aminoacid complexes by methylcobalamin. Sci. Total. Environ. 100, 337-346.

Braman, R.S., Tompkins, M.A., 1979. Separation and determination of nanogram amounts of inorganic tin and methyltin compounds in the environment. Anal. Chem. 51, 12-19.

Byrd, J.T., Andreae, M.O., 1982. Tin and methyltin species in seawater: concentrations and fluxes. Science 218, 565-569.

Chen, B.W., Jiang, G.B., Yang, R.Q., Liu, J.Y., 2006. Methylation of tin(II) by methyl iodide: Influences of different environment factors on the efficiency and reaction kinetics. Appl. Organomet. Chem. 20, 161167.

Dizikes, L.J., Ridley, W.P., Wood, J.M., 1978. A mechanism of the biomethylation of tin by reductive $\mathrm{Co}-\mathrm{C}$ bond cleavage of alkylcobalamins. J. Am. Chem. Soc. 100, 1010-1012.

Donard, O.F.X., Rapsomanikis, S., Weber, J.H., 1986. Speciation of inorganic tin and alkyltin compounds by atomic absorption spectrometry using electrothermal quartz furnace after hydride generation. Anal. Chem. 58, 772-777.

Donard, O.F.X., Quevauviller, P., Bruchet, A., 1993. Tin and organotin speciation during wasterwater and sludge treatment processes. Water Res. 27, 1085-1089.

Fanchiang, Y.T., Wood, J.M., 1981. Alkylation of tin by alkylcobalamins, kinetics and mechanism. J. Am. Chem. Soc. 103, 5100-5103.

Han, J.S., Weber, J.H., 1988. Speciation of methyl- and butyltin compounds and inorganic tin oysters by hydride generation atomic absorption spectrometry. Anal. Chem. 60, 316-319.

Jiang, G.B., Xu, F.Z., 1996. Speciation analysis of butyltin species in water by gas chromatography with flame photometric detection using quartz surface-induced tin emission. Appl. Organomet. Chem. 10, $77-$ 82.

Jiang, G.B., Ceulemans, M., Adams, F.C., 1996. Optimization study for the speciation analysis organotin and organogermanium compounds by on-column capillary gas chromatography with flame photometric detection using quartz surface-induced luminescence. J. Chromatogr. A $727,119-129$.

Jiang, G.B., Zhou, Q.F., He, B., 2000. Speciation of organotin compounds, total tin, and major trace metal elements in poisoned human organs by gas chromatography-flame photometric detector and inductively coupled plasma-mass spectrometry. Environ. Sci. Technol. 34, 2697-2702.

Maguire, R.J., Chau, Y.K., Bengert, G.A., Hale, E.J., Wong, P.T.S., Kramar, O., 1982. Occurrence of organotin compounds in Ontario lakes and rivers. Environ. Sci. Technol. 16, 698-702.

Maguire, R.J., Tkacz, R.J., Chau, Y.K., Bengert, G.A., Wong, P.T.S., 1986. Occurrence of organotin compounds in water and sediment in Canada. Chemosphere 15, 253-274.

Pratt, J.M., 1972. Inorganic Chemistry of Vitamin B12. Academic Press, London.

Quevauviller, P., Lavigne, R., Pinel, R., Astruc, M., 1989. Organo-tins in sediments and mussels from the Sado estuarine system (Portugal). Environ. Pollut. 57, 149-166.

Schebek, L., Andreae, M.O., Tobschall, H.J., 1991. Methyl- and butyltin compounds in water and sediment of the Rhine river. Environ. Sci. Technol. 25, 871-878.

Seidel, S.L., Hodge, V.F., Goldberg, E.D., 1980. Tin as an environmental pollutant. Thalassia Jugosl 16, 209-223.

Tugrul, S., Balkas, T., Goldberg, E.D., 1983. Methyltins in the marine environment. Mar. Pollut. Bull. 14, 297-303. 